\title{
Mistä on tieteellinen ajattelu tehty?
}

\author{
MINNAKAARTINEN-KOUTANIEMI
}



\begin{abstract}
Filosofian tohtori Minna Kaartinen-Koutaniemi tarkastelee yliopistopedagogiikan alaan kuuluvassa väitöstutkimuksessaan Tieteellinen ajattelu yliopisto-opinnoissa kolmen oppiaineen, psykologian, teologian ja farmasian, yliopisto-opiskelijoiden tieteellistä ajattelua. Tieteellinen ajattelu ja tietokäsitys vaihtelevat riippuen opiskelijan iästä, opintovaiheesta ja opiskelualasta. Tutkimus osoittaa tieteellisen ajattelun kehittymisen ja tieteen tekemisen taitojen oppimisen olevan yhteydessä opettajien antamaan opetukseen sekä oppiainelaitoksen pedagogisiin ratkaisuihin. Opiskeluympäristö ja opettajien tuki erityisesti asiantuntijaksi kehittymisessä ja opinnäytetöiden ohjauksessa osoittautui opiskelijoille tärkeäksi.
\end{abstract}

T utkimukseni tavoitteena oli vastata neljään tutkimuskysymykseen:

1. miten tieteellinen ajattelu eroaa eri opintojen vaiheessa olevien tai eri tieteenalaa edustavien opiskelijoiden välillä?

2. miten opiskelijat oppivat tieteellisen ajattelun taitoja?

3. miten tieteellinen ajattelu kehittyy opintojen aikana? ja

4. mitä tieteellinen ajattelu yliopistopedagogiikan näkökulmasta on?

Opiskelijoiden tieteellinen ajattelu ja tieteen tekemisen taidot ovat akateemisen koulutuksen keskeinen oppimistavoite ja erityispiirre. Yliopistoopinnot edellyttävät tieteellisen ajattelun taitojen oppimista ja hyvän tieteellisen käytännön omaksumista. Tällä tarkoitetaan kriittistä ajattelua, lähdekritiikkiä, tiedon luotettavuuden arvioinnin taitoja, tutkimusmenetelmien ja -etiikan hallitsemista sekä tieteellisen kirjoittamisen taitoja. Tieteellisen ajattelun kehittymisessä on olennaista tietokäsityksen kehittyminen relativistiseksi, tiedon moniulotteisuuden ja tilannesidonnaisuuden ymmärtäminen sekä oman näkökulman muodostaminen.

Nämä ovat yleisiä vaatimuksia, joita täydennetään alakohtaisilla erityisvaatimuksilla. Opiskelijan tulee tuntea oman alansa perustiedot, tutkimusperinne ja perustutkimus, jotta hän voisi toimia alaansa erikoistuneena asiantuntijana.
Tutkimukseni teoreettinen viitekehys perustuu oletukseen opiskelijoiden tieteellisen ajattelun ja tietokäsityksen kehittymisestä yliopisto-opintojen aikana sekä näiden yhteydestä tutkimuksen tekemisen taitojen oppimiseen. Teoreettiseen viitekehykseen sisältyy lisäksi käsitys, jonka mukaan opiskelijoilla on erilaiset kyvyt ja taidot oppia tieteellistä ajattelua. Siksi tieteellinen ajattelu ja tietokäsitys kehittyvät yksilöllisesti. Eri tieteenalojen opiskelijoiden välisessä vertailussa otetaan myös huomioon tieteenalalla käytetyt tiedon arvioinnin kriteerit ja opiskelijoilta edellytetyt kriittisen ajattelun taidot.

Yliopistopedagogiikassa tietokäsityksellä viitataan käsitteenä opiskelijoiden toimintaan eli siihen, miten opiskelijat soveltavat tietoa käytännöllisissä tilanteissa, miten he jäsentelevät tietoa ja miten he yhdistävät uutta tietoa aiemmin oppimaansa. Yliopistopedagogisissa tutkimuksissa on kysytty, mitä uskomuksia yksilöillä on tiedosta, miten he rakentavat tietoa, mistä tietoa hankitaan ja miten ajattelun taidot kehittyvät.

Tutkimuksessani yhdistetään käsitepariksi tieteellinen ajattelu ja tietokäsitys käännöksenä englanninkielisestä personal epistemology -käsitteestä. Tieteellinen ajattelu ja tietokäsitys määritellään erityisesti Hoferin ja Pintrichin kehittelemän teoreettisen mallin neljän osa-alueen perusteella. Siinä kuvataan yksilön ymmärrys ja käsitys 
1) tiedon varmuudesta,

2) tiedon yksi/moniulotteisuudesta,

3) tiedon perustasta ja lähteestä sekä

4) tietämisen perustelusta.

Kuhn on testannut neljän osa-alueen mallia empiirisesti ja laatinut sen pohjalta teoreettisen mallin yksilön aikuisiän ajattelun kehittymisestä. Mallin toisena ääripäänä on absolutismi eli mustavalkoinen ajattelu, jossa tieto ymmärretään yksiselitteisesti oikeaksi tai vääräksi, sen oletetaan perustuvan empiirisiin havaintoihin ja tiedon lähteeksi hyväksytään ulkoiset auktoriteetit. Toisessa ääripäässä on evaluatismi eli tieto ymmärretään muuttuvaksi, kehittyväksi ja suhteelliseksi, sen oletetaan perustuvan argumentointiin, tieteelliseen näyttöön ja ratkaisuihin erilaisten vaihtoehtojen välillä sekä olevan tavoitettavissa kriittisen ajattelun keinoin. Välivaiheena ääripäiden välillä on relativismi, jossa tietoa pidetään epävarmana ja havaitut ristiriidat tieteellisten väitteiden välillä hyväksytään esimerkiksi pitämällä niitä eriävinä mielipiteinä. Tässä tutkimuksessa Kuhnin mallia ajattelun kehittymisestä sovelletaan erityisesti opiskelijaprofiilien tarkastelussa.

Tutkimusaineistona olivat 53 psykologian kolmen eri vuosikurssin opiskelijan haastattelut sekä vertailuaineistona 19 viimeisen vuoden teologian ja 15 farmasian opiskelijan haastattelut. Opiskelijat valittiin aloilta, joilla on ammatillisen pätevyyden tarjoavat koulutusohjelmat. Lisäksi ne edustavat peruslähtökohdiltaan erilaisia tieteenaloja.

Tutkimusasetelmana on yhden tieteenalan poikittaisotanta kolmelta eri vuosikurssilta sekä kolmen tieteenalan välinen vertailuotanta. Aineiston keruumenetelmäksi valittiin puolistrukturoitu haastattelu, jossa kysymykset sekä niiden järjestys ja muoto olivat kaikille haastateltaville samat.

Haastattelua suunnitellessa pidettiin mielessä, ettei tieteellistä ajattelua ja tietokäsityksiä voida tutkia suorilla kysymyksillä, kuten millainen tietokäsitys sinulla on. Niiden sijaan käytettiin aihetta epäsuorasti kartoittavia konkreettisia kysymyksiä, joihin opiskelijat vastasivat kuvaamalla toimintaansa arjen tilanteissa ja kertomalla havainnollistavia esimerkkejä.

Haastatteluaineistosta muodostettiin sisällönanalyysillä kolme pääluokkaa alaluokkineen kuvaamaan opiskelijoiden käsityksiä tieteellisestä ajattelusta, tietokäsityksestä ja asiantuntijaksi kehittymisestä. Lisäksi kukin opiskelija luokiteltiin vastauksensa perusteella yhteen kolmesta tieteellistä ajattelua edustavasta profiiliryhmästä.

\section{Tulokset: sisältölähtöiset luokat ja vertailutulokset}

Kolme pääluokkaa alaluokkineen muodostettiin psykologian kolmen vuosikurssin opiskelijoiden vastauksista. Määrälliset tulokset tiivistettiin laskemalla, kuinka moni tutkittava kunkin pää- ja alaluokan asian mainitsi.

Ensimmäisessä pääluokassa eritellään opiskelijoiden kriteerit tiedon tieteellisyyden ja luotettavuuden arvioimiseksi. Opiskelijoita pyydettiin perustelemaan toimintatapansa tilanteissa, joissa tieteellisten tutkimusten tai tietojen väliltä löytyi ristiriitoja. Lisäksi heitä pyydettiin kertomaan esimerkkejä tilanteista, joissa he olivat suhtautuneet tieteelliseen tietoon kriittisesti ja epäilleet sen todenmukaisuutta. Opiskelijoilta kysyttiin myös, olivatko tenttikirjojen tiedot heidän mielestään luotettavia sekä perustelemaan ne tietolähteet, joita he pitivät luotettavimpina.

Toiseen pääluokkaan on kerätty opiskelijoiden mielipiteet asiantuntijaksi kasvamisen edellytyksistä. Kolmannessa pääluokassa opiskelijoiden vastaukset kertovat siitä, millaista ajattelua heiltä on pääaineen opinnoissa vaadittu ja miten se eroaa muista aloista. Opiskelijat kuvailevat toisaalta vaatimuksia, mutta samalla tieteenalaansa opiskeluympäristönä.

\section{Tulokset: psykologian kolmen vuosikurssien opiskelijoiden vertailu}

Ensimmäisenä teemana käsittelen psykologian kolmen vuosikurssin opiskelijoiden välisen vertailun. Selkeitä kehityssuuntia toiselta vuosikurssilta neljännelle ja edelleen kuudennelle siirryttäessä ei luokittelun tuloksista löytynyt. Sisällöllisesti toisen vuosikurssin opiskelijoiden vastaukset olivat analyyttisiä ja he erittelivät esimerkiksi tieteellisen ja arkiajattelun välisiä eroja. Osa vastaajista tosin melko mekaanisesti. Vastaukset ilmensivät sekä itsevarmuutta että epävarmuutta suhteessa omiin tutkimustaitoihin ja tieteellisiin valmiuksiin asiantuntijaksi kehittymisessä.

Neljännen vuosikurssin opiskelijoiden vastausten analyysi erosi useissa alaluokissa toisen ja kuudennen vuoden opiskelijoista. Heidän vastauksistaan välittyi vahvasti pohdinta käynnissä olleista opintojaksoista. Ensimmäiset itsenäiset tutkimusharjoitustyöt ja toisaalta ammatillista orientaatiota edellyttäneet valinnat olivat opiskelijoille ajankohtaisia. 
Kuudennen vuosikurssin opiskelijoiden vastaukset olivat edellisiin verrattuna monipuolisempia ja yksilöllisempiä. Valmistumisvaiheen opiskelijat olivat jo suuntautumassa tutkinnon suorittamisen jälkeiseen työelämään ja moni heistä suoritti työharjoitteluaan tai viimeisteli pro gradu -tutkielmaansa. Ryhmien vastauksia sisällöllisesti ja laadullisesti verrattaessa voidaan sanoa tieteellisen ajattelun kehittyneen psykologian opintojen aikana.

\section{Tulokset: viimeisen vuoden opiskelijoiden vertailu}

Kolmen tieteenalan psykologian, teologian ja farmasian opiskelijoiden $(\mathrm{n}=52)$ aineistojen vertailussa löytyi myös mielenkiintoista vaihtelua. Tutkimuksen perusteella tutkimustaidot ja tieteellinen ajattelu olivat muotoutuneet tieteenaloilla eri suuntiin. Erilaisuutta selittivät koulutusohjelman rakenne, tieteenalojen pedagogiset ratkaisut ja akateemiset käytännöt sekä opiskelijoiden ammatilliset orientaatiot.

Kolmen tieteenalan viimeisen vuoden opiskelijoiden vastausten perusteella voi olettaa, että psykologian opiskelijat haastetaan kriittiseen ajatteluun. Heiltä myös edellytetään kvantitatiiviseen tutkimukseen perustuvan tiedon hankintaa ja empiirisen tiedon käsittelyä. Teologian opiskelijoiden vastauksissa korostui erityisesti intuitio tieteellisen tiedon arvioinnin kriteerinä. He kertoivat soveltavansa intuitiota esimerkiksi ristiriitaisen tiedon käsittelyssä, jolloin he tekivät valintansa faktojen välillä punnitsemalla vaihtoehtoja itseluottamukseensa ja intuitioonsa nojaten. Farmasian opiskelijat puolestaan korostivat tutkimusalansa empiirisen tiedon luonnetta. Se edellyttää heidän mielestään tiedon mieleen painamista ja täsmällistä muistamista. Lisäksi he korostivat vahvaa ammatillisen osaamisen ja työelämän vaatimusten näkökulmaa tieteellisiä taitojaan pohtiessaan. Kolmen eri alan opiskelijoiden vastauksista kävi ilmi tiedealakohtaiset erityispiirteet sekä välillisesti myös menetelmäopintojen tavoitteiden, määrien ja opetuskäytäntöjen erot.

\section{Tulokset: Opiskelijaprofililit}

Kolmas teema tutkimustulosten tarkastelussa on opiskelijaprofiilit, joilla tarkasteltiin opiskelijoiden haastatteluja yksilöllisesti sen perusteella, kuinka yhtenäisiä tai epäyhtenäisiä opiskelijoiden vastaukset kokonaisuudessaan olivat. Sisällönanalyy- sillä vahvistettiin kolme opiskelijaprofiilia, joista yhdessä on kaksi alaluokkaa.

Absolutistisen profiilin ryhmässä opiskelijoiden vastaukset olivat pinnallisia. Opiskelijat luetteloivat tiedon arvioinnin kriteereitä perustelematta vastauksiaan tai ilmaisemalla subjektiivisia mielipiteitä. Vastaukset olivat epätäsmällisiä, eivätkä opiskelijat muuttaneet vastaustaan, kun heitä pyydettiin tarkentamaan näkemystään.

Relativististen profiilien ryhmään luokitelluissa vastauksissa oli sekä evaluativistisia että absolutistisia piirteitä. Vastausten perusteella opiskelijoille oli jonkin verran evaluativistinen käsitys tiedon varmuuden ja luotettavuuden arvioimisesta. Esimerkkien ja oman toiminnan kuvauksessa kuitenkin paljastui käytännön ja ajattelun välinen ristiriita.

Evaluativististen profiilien ryhmään muodostettiin kaksi alaluokkaa, joista ensimmäisessä eli niukasti evaluativististen profiilien ryhmässä opiskelijoiden vastaukset olivat evaluativistisia, vaikkakin hiukan lyhyitä ja sisällöltään niukkoja. Mikäli haastattelija pyysi tarkentamaan vastauksia, opiskelijat toistivat aiemmin sanomaansa eivätkä tarkentaneet tai syventäneet vastaustaan.

Toisessa eli systemaattisesti evaluativististen profiilien luokassa opiskelijoiden vastaukset olivat analyyttisiä ja reflektoivia. Lisäksi ne olivat sisällöltään johdonmukaisia tietojen, taitojen ja käytännön esimerkkien välillä. Opiskelijat myös perustelivat vastauksensa monipuolisilla näkökulmilla. He kuvasivat oma-aloitteisesti ajattelunsa muutoksia ja kertoivat kriittisen ajattelun soveltamisesta ongelmanratkaisutilanteissa.

Opiskelijaprofiilien luokittelua verrattiin ristiintaulukoimalla vastaajien ikään, opiskeluvaiheeseen ja tieteenalaan. Tulosten mukaan iällä näytti olevan merkitystä siihen, mihin profiiliryhmään opiskelija kuului. Nuorimmat opiskelijat luokiteltiin tavallisimmin absolutististen tai relativististen profiiliryhmään. Vastaavasti yli 24-vuotiaat, muutamaa poikkeusta lukuun ottamatta, kuuluivat evaluativististen profiilien ryhmään. Tieteenalakohtaisista eroista mielenkiintoisinta oli, että psykologian ja teologian opiskelijoita keskimäärin nuoremmat farmasian opiskelijat kuuluivat pääosin absolutistisen profiilin ryhmään. Psykologian opiskelijat iästä riippumatta kuuluivat kuitenkin yleisimmin evaluativististen profiilien ryhmään. Teologian opiskelijoista kolmasosa sijoittui absolutististen ja noin puolet evaluativististen profiilien ryhmiin. Relativistiseen opiskelijaprofiiliryhmään luokitte- 
lu ei määrällisesti eronnut kolmen tieteenalan viimeisen vuoden opiskelijoiden kesken.

Yhteenvetona voidaan sanoa tutkimukseen osallistuvista 87 opiskelijasta seuraavaa. Opiskelijat vertasivat vastauksissaan opiskelun alkuvaihetta nykytilanteeseensa ja totesivat ajattelun- ja opiskelutaitojen kehittyneen erityisesti tietoa toistavasta ja yhdistelevästä lähestymistavasta kokonaisvaltaisempaan ymmärrykseen ja kykyyn soveltaa tietoa ammatillisesti. Lisäksi erityisesti viimeisen vuosikurssin opiskelijoilla oli omakohtainen kokemus siitä, miten oppimisympäristön haasteet ja vaatimukset olivat edellyttäneet uusien taitojen oppimista sekä ajattelutapojen uudelleenarviointia.

Tutkimuksen tulosten perusteella voi olettaa, että Helsingin yliopiston psykologian alan koulutusohjelma ja haastateltujen oppimisympäristö ovat tutkimuslähtöisiä ja sellaisenaan tukevat opiskelijoiden tieteen tekemisen taitoja. Psykologian opiskelijoiden tiedot ja taidot tieteellisestä ajattelusta ovat jo toiselta vuosikurssilta alkaen hyvät ja opiskelijat arvostavat saamaansa tutkimustaitojen ja -menetelmien koulutusta. Tutkimuksen perustaitoja opetetaan opiskelijoiden mukaan konkreettisesti lähes kaikilla opintojaksoilla vähintäänkin läpäisyperiaatteella opintojen alusta alkaen. He olisivat kuitenkin toivoneet lisätukea opettajiltaan tieteellisen ajattelun ja asiantuntijuuden kehittymisen pohtimiseen. Lisäksi vastauksissa korostui tekemällä oppimisen tärkeys, mikä psykologian laitoksella on järjestetty osallistavilla opetusmenetelmillä ja erillisillä harjoituskursseilla.

Teologian ja farmasian tiedekuntien koulutusohjelmissa ei opiskelijoiden vastausten perusteella ole onnistuttu yhtä hyvin tutkimuslähtöisen oppimisympäristön luomisessa. Analyysi haastatteluaineistosta paljasti, ettei teologian ja farmasian koulutus haastanut kaikkia opiskelijoita riittävästi tieteellisen ajattelun ja tutkimustaitojen oppimiseen. Opiskelijoiden vastausten perusteella opinnoista saattoi suoriutua melko pinnallisella tenttiin lukemisella. Toisaalta vahva ammatillinen orientaatio hyväksyttiin syyksi siihen, että opinnoissa syvennyttiin erityisesti käytännöllisessä työssä vaadittuihin tietoihin ja taitoihin tieteellisen lähestymistavan kustannuksella.

Teologian ja farmasian opiskelijat esittivät joitakin toiveita tieteellisen ajattelunsa kehittämisen tueksi. He toivoivat esimerkiksi opettajilta kriittisyyttä ja analyyttisyyttä erityisesti opiskelumateriaaleja, kuten tenttikirjoja, valittaessa. Kurssivaa- timuksiin haluttiin entistä enemmän alan uusimpia tutkimuksia, kuten tutkimusartikkeleita, osittain vanhentuneiden ja pinnalliselle tasolle jäävien tenttikirjojen tilalle.

\section{Pohdinta}

Tutkimustuloksista voi päätellä, että tutkimusintensiiviseksi kuvatusta yliopistosta valmistuvilta vaaditaan ja edellytetään tutkimusvalmiuksia. Psykologian opiskelijoiden vastausten perusteella tutkimuslähtöisyys opetuksessa toteutuu ja tutkimuksen tekemisen taidot sekä tieteellinen ajattelu kehittyvät jo ensimmäisistä opiskeluvuosista alkaen.

Vertailuaineisto teologian ja farmasian viimeisen vuoden opiskelijoista paljastaa, ettei kaikilta yliopistosta valmistuvilta edellytetä samanlaista tieteellistä osaamista psykologian opiskelijoihin verrattuna. Maisteriksi valmistuu muodollisesti päteviä tieteentekijöitä, joille asiantuntijuus merkitsee ensi sijassa työelämässä vaadittuja ja ammatin edellyttämiä taitoja, ei niinkään tieteellisen tutkimuksen tekemisen osaamista.

Väitöskirjani tutkimustulosten soveltaminen yliopistopedagogiikkaan edellyttää yliopisto-opetuksen keskeisen tavoitteen, tieteellisen ajattelun ja tutkimustaitojen oppimisen, korostamista kautta opetuksen ja opiskelun vaiheiden. Käytännössä tämä näkyy esimerkiksi siten, että opettajille ja opiskelijoille on lähtökohtaisesti selvää, miten tieto osoitetaan todeksi kullakin tieteenalalla ja oppiaineessa sekä mitä opiskelijoita edellytetään tutkimuksen tekemisen ja tieteellisen ajattelun opiskelun taidoissa. Pulmana aiempien tutkimusten perusteella näyttäisi olevan, ettei opiskelijoille määritellä yksiselitteisesti tieteenalan tai oppiaineen tietokäsitystä eikä tutkimustraditiota. Se tuntuu olevan ns. hiljaista tietoa, joka opitaan sosiaalistumalla ja osittain sattumanvaraisestikin opintojen ohessa. Selväksi tulisi tehdä myös tieteenalan tutkintorakenteen sisältämän koulutuksen keskeiset tavoitteet ja niiden perustelut, joista usein käy ilmi sekä tietokäsitys että se, miten tieto tieteenalalla osoitetaan todeksi.

Teksti on lectio praecursoria hieman lyhennettynä. Väitöstilaisuus oli 24.4.2009 Helsingin yliopistossa. Vastaväittäjänä toimi professori Marja Vauras Turun yliopistosta. 